\title{
ACTIVITY OF BETEL LEAF EXTRACT AGAINST BACTERIA CAUSING DENTAL CARIES
}

\author{
Manabendra Nayak', Rahul Nayak², Lukpu Ngulom ${ }^{3}$ \\ ${ }_{1}^{1}$ Postgraduate Teacher of Medicine, National Board of Examination, Senior Consultant, Department of Medicine, Down Town Hospital, \\ Guwahati. \\ ${ }^{2}$ Assistant Professor, Department of Microbiology, Assam Down Town University, Guwahati. \\ 3Postgraduate Trainee, Department of Microbiology, Assam Down Town University, Guwahati.
}

\section{ABSTRACT}

\section{BACKGROUND}

Pathogens present in the mouth are responsible for oral and dental infections. Dental caries is a common disease that results in tooth loss and cavitations. The purpose of the study was to determine the activity of P. betel leaf extracts against the bacteria isolated from oral region (Teeth).

\section{MATERIALS AND METHODS}

The teeth swabs were collected from patients suffering from dental caries. The bacteria present in the samples were isolated and identified by morphological and biochemical characteristics. Extracts preparation was carried out in different solvents (Ethanol, methanol and aqueous).

\section{RESULTS}

The isolated bacteria were subjected to antibacterial sensitivity test by agar well diffusion method against different concentrations of ethanol, methanol and aqueous extract. All the extracts showed inhibitory effect against the tested bacteria.

\section{CONCLUSION}

In conclusion it can be said betel leaves have potent antimicrobial effect on oral bacteria that lead to infection in mouth or normally present in mouth. So from the present study, it can be concluded that Piper betel leaf can be a tool for fighting against the oral pathogenic bacteria which are gaining resistance to the drugs available in the market.

\section{KEYWORDS}

Dental Caries, Piper Betel, Antibacterial Sensitivity, Phytochemical.

HOW TO CITE THIS ARTICLE: Nayak M, Nayak R, Ngulom L. Activity of betel leaf extract against bacteria causing dental caries. J. Evolution Med. Dent. Sci. 2016;5(87):6454-6460, DOI: 10.14260/jemds/2016/1460

\section{BACKGROUND}

Plants are rich source of active metabolites that affects against variety of microbial species. New drugs are needed to eradicate the resistant microorganisms because existing antibacterial compounds are going to be resistant against a number of microbial strains and are becoming superseded.[1] Antibacterial compounds extracted from plants are not related with side effects as the laboratory prepared compounds and can be successfully used against many infectious diseases.[2] Piper betel plant leaves are rich in a wide variety of secondary metabolites such as phenolic compounds, volatile oils, fatty acids and hydroxy fatty acids which in vitro illustrate the antibacterial properties and might be used as a choice, useful, cheap and safe antibacterial for the treatment of microbial infections. [3]

Piper betel L. belongs to family Piperaceae commonly known as Paan. The family of Piperaceae belonging to super order Nymphaeiflloraea, order Piperales and genus Piper of family Piperaceae commonly known as pan comprises about 10 genera, 2000 species.

Financial or Other, Competing Interest: None.

Submission 14-09-2016, Peer Review 20-10-2016,

Acceptance 26-10-2016, Published 28-10-2016.

Corresponding Author:

Dr. Manabendra Nayak

House No. 09, Raghunath Choudhury Path,

Lachit Nagar, Guwahati-781007, Assam.

E-mail:dr.mnayak@yahoo.co.in

DOI: $10.14260 /$ jemds $/ 2016 / 1460$
The genus Piper (Piperaceae) is largely distributed in tropical and subtropical regions of the world.[4] Over 700 species of Piper betel has been distributed in both the hemispheres of world. Of these, 30 species have been recorded in India, 18 in Srilanka and 3 are endemic. Piper betel is cultivated in India, Srilanka, Malaysia, Indonesia, Philippine Islands and East Africa. [5]

Betel leaf is mostly consumed in Asia, as betel quid or in paan with or without tobacco, in an addictive psychological formation which may have an adverse health effects. The betel plant is evergreen perennial with glossy heart-shaped leaves. Betel is notable for staining the teeth of regular users. The parts of piper betel utilised are leaves, roots, stems, stalks and fruits. Piper betel has light yellow aromatic essential oil with sharp burning taste. The leaves are pungent, bitter, sweetish, bitter and acrid in nature.[6]

\begin{tabular}{|c|c|}
\hline \multicolumn{2}{|c|}{ Vernacular Names $[7,8]$} \\
\hline English & Betel \\
\hline Hindi & Paan \\
\hline Tamil & Vetrilai \\
\hline Malaysia & Sirihmelayu \\
\hline Thai & Pelu \\
\hline Sanskrit & Nagavallari \\
\hline Assamese & Paan \\
\hline \multicolumn{2}{|c|}{ Table 1. Vernacular Names of Piper Betel L. } \\
\hline
\end{tabular}

The objective of this study includes isolating and identification of bacteria present in the oral region and to 
study the antibacterial activity of betel leaf extract against bacteria isolated.

\section{MATERIALS AND METHODS Clinical Samples}

Teeth swabs were collected from patients suffering from dental caries using cotton swabs. The teeth swab collected in sterile container is brought to the laboratory and cultured. The teeth swab was inoculated in the nutrient agar plates directly by streaking back and forth. The plate was incubated overnight at $37^{\circ} \mathrm{C}$. The plate was looked for single bacterial colony and the single colony was again sub-cultured by streaking method.

The isolated bacteria were characterised based on their colony morphology, shape, colour, staining and different biochemical tests. The different staining techniques performed for the characterisation of the isolated bacteria includes Gram's staining, Capsule staining and Endospore staining. The different biochemical tests performed for the characterisation of the isolated bacteria includes Indole test, Methyl-Red test, Citrate utilisation test, Catalase test. The test organisms were identified by VITEK instrument at microbiology laboratory, down town hospital, Guwahati, Assam.

\section{Plant Sample}

Betel leaves were collected from market of Guwahati. After collecting, the leaves were washed and shade dried. After drying, the leaves were grinded in mortal pestle till it become powdered form.

\section{Extract Preparation \\ Water Extract}

20 gram of the powdered betel leaf sample was weighed and taken in $250 \mathrm{~mL}$ of distilled water and kept for 3 nights. The extract was then filtered using Whatman no. 1 filter paper and allowed to evaporate in water bath at $50^{\circ} \mathrm{C}$. The dried extract is stored in refrigerator for further use. "The extract is stored at $4^{\circ} \mathrm{C}$ for less than one year and as per literature searched, it was mentioned no preservative is required for the storage of the extract for less than one year." $[9][10]$

\section{Methanol Extract}

20 gram of the powdered betel leaf sample was weighed and taken in $250 \mathrm{~mL}$ of $70 \%$ methanol and kept for 3 nights. The extract was then filtered using Whatman no. 1 filter paper and allowed to evaporate in water bath at $50^{\circ} \mathrm{C}$. The dried extract is stored in refrigerator for further use. "The extract is stored at $4^{\circ} \mathrm{C}$ for less than one year and as per literature searched, it was mentioned no preservative is required for the storage of the extract for less than one year."[9][10]

\section{Ethanol Extract}

20 gram of the powdered betel leaf sample was weighed and taken in $250 \mathrm{~mL}$ of $70 \%$ ethanol and kept for 3 nights. The extract was then filtered using Whatman no. 1 filter paper and allowed to evaporate in water bath at $50^{\circ} \mathrm{C}$. The dried extract is stored in refrigerator for further use. "The extract is stored at $4^{\circ} \mathrm{C}$ for less than one year and as per literature searched, it was mentioned no preservative is required for the storage of the extract for less than one year." [9][10]

\section{Phytochemical Analysis}

After the successful extraction of the plant, the resulted extracts are subjected to various phytochemical screening. Most of the plants contain medicinally active secondary metabolites. These metabolites are alkaloids, carbohydrates, glycosides, saponins, tannins, flavonoids, terpenoids, flavonoids, proteins and phenolic compounds. So all the extracts will be subjected to different chemical tests to detect the presence of constituent.[10]

\section{Antibacterial Test}

The antibacterial activity of Piper betel leaf extract was determined by Agar Well Diffusion method against the bacteria isolated from the oral region (Teeth). In this method, pure isolate of each bacterium was sub-cultured in nutrient broth at $37^{\circ} \mathrm{C}$ for 24 hours. About 100 microlitre of each test bacterium was spread with the help of sterile spreader on to a sterile Mueller-Hinton agar plate, so as to achieve a confluent growth. The plates were allowed to dry and then a sterile metal borer of diameter $8 \mathrm{~mm}$ was used to form three wells in each of the agar plates. Each of the three wells was labelled for three different extract solutions. Subsequently 50, 30, 20 microlitre volume of each extract was poured in relatively labelled well on nutrient agar plates. The plates were then incubated at $37^{\circ}$ $\mathrm{C}$ for 24 hours. After completion of incubation period, zones of inhibition were measured and recorded to the nearest size in millimetres.

\section{Preparation of Standard Concentration of the Extracts}

$1 \mathrm{gm}$ of each alcoholic extracts was dissolved in $1 \mathrm{~mL}$ of Dimethyl sulphoxide (DMSO) and $1 \mathrm{gm}$ of aqueous extract was dissolved in distilled water. Thus, $1 \mathrm{~g} / \mathrm{mL}$ stock was obtained as a standard concentration of alcoholic extracts. Aqueous was sterilised using $0.40 \mu \mathrm{m}$ membrane filter.

\section{RESULTS}

\section{Staining Characteristics of the Isolates}

Out of the 30 isolated bacteria 24 were gram positive and 6 gram negative, 21 bacteria possesses capsule and 20 bacteria contains endospore.

\section{Biochemical Test of the Isolates}

All the 30 bacterial isolates were Indole negative, 24 bacteria were MR positive, 27 utilised citrate and 20 bacteria were Catalase positive.

\section{Identification of the Test Organisms}

The test organisms were identified by VITEK instrument at Microbiology Laboratory, Down Town Hospital. Predominantly, three organisms were identified to be Staphylococcus xylosus, Klebsiella pneumoniae and Bacillus sp. 
Phytochemical Analysis of Extracts of P. Betel Leaf

\begin{tabular}{|c|c|c|c|c|c|}
\hline \multicolumn{2}{|c|}{ Phytochemical Tests } & $\begin{array}{l}\text { Ethanol } \\
\text { Extract }\end{array}$ & $\begin{array}{l}\text { Methanol } \\
\text { Extract }\end{array}$ & $\begin{array}{c}\text { Aqueous } \\
\text { Extract }\end{array}$ & Interference \\
\hline \multirow{2}{*}{ Detection of Alkaloids } & Mayer's Test & +ve & +ve & +ve & \multirow{2}{*}{ Alkaloids } \\
\hline & Wagner's Test & $+\mathrm{ve}$ & $+\mathrm{ve}$ & $+\mathrm{ve}$ & \\
\hline \multirow{3}{*}{ Detection of Carbohydrates } & Molisch's Test & -ve & -ve & -ve & Carbohydrates \\
\hline & Barfoed's Test & -ve & -ve & -ve & Carbohydrates \\
\hline & Benedict's Test & -ve & $+\mathrm{ve}$ & -ve & Reducing sugar \\
\hline \multirow{2}{*}{ Detection of Glycosides } & Liebermann's Test & $+\mathrm{ve}$ & $+\mathrm{ve}$ & +ve & \multirow{2}{*}{ Steroids Ring } \\
\hline & Salkowski's Test & $+\mathrm{ve}$ & $+\mathrm{ve}$ & $+\mathrm{ve}$ & \\
\hline Detection of Saponins & Forth Formation Test & $+\mathrm{ve}$ & $+\mathrm{ve}$ & +ve & Saponins \\
\hline \multirow{2}{*}{ Detection of Tannins } & Ferric Chloride Test & $+\mathrm{ve}$ & $+\mathrm{ve}$ & $+v e$ & \multirow{2}{*}{ Tannins } \\
\hline & Gelatin Test & $+\mathrm{ve}$ & $+\mathrm{ve}$ & +ve & \\
\hline \multirow{3}{*}{ Detection of Flavonoids } & Ferric Chloride Test & $+\mathrm{ve}$ & $+\mathrm{ve}$ & $+\mathrm{ve}$ & \multirow{3}{*}{ Flavonoids } \\
\hline & $\mathrm{NaOH}$ Test & $+\mathrm{ve}$ & $+v e$ & + ve & \\
\hline & Alkaline Reagent Test & $+\mathrm{ve}$ & -ve & -ve & \\
\hline Detection of Terpenoids & Ferric Chloride Test & $+\mathrm{ve}$ & $+\mathrm{ve}$ & $+\mathrm{ve}$ & Terpenoids \\
\hline Detection of Steroids & Carr-Price Reagent & + ve & $+\mathrm{ve}$ & +ve & Steroids \\
\hline Detection of Proteins & Ninhydrin Test & $+\mathrm{ve}$ & $+\mathrm{ve}$ & $+\mathrm{ve}$ & Amino Acids \\
\hline $\begin{array}{c}\text { Detection of Phenolic } \\
\text { Compounds }\end{array}$ & Ferric Chloride Test & $+\mathrm{ve}$ & $+\mathrm{ve}$ & $+\mathrm{ve}$ & Phenolics \\
\hline \multicolumn{6}{|c|}{ Table 2. Phytochemical Analysis of Extracts of P. Betel Leaf } \\
\hline
\end{tabular}

Antibacterial Activity of Piper Betel Leaf Extracts against the Bacteria Isolated from the Oral Region

Antibacterial Activity of Ethanol Extract of Piper Betel Leaf

The ethanol extract of Piper betel leaf against Staphylococcus xylosus showed a zone of clearance of diameter of $40 \mathrm{~mm}$ $(50 \mu \mathrm{L}), 29 \mathrm{~mm}(30 \mu \mathrm{L})$ and $27 \mathrm{~mm}(20 \mu \mathrm{L})$ on $24 \mathrm{hrs}$. incubation. The ethanol extract was effective against Klebsiella pneumoniae and showed a zone of clearance of diameter of 30 $\mathrm{mm}(50 \mu \mathrm{L}), 25 \mathrm{~mm}(30 \mu \mathrm{L})$ and $23 \mathrm{~mm}(20 \mu \mathrm{L})$ on $24 \mathrm{hrs}$. of incubation. The ethanol extract was effective against Piper betel leaf against Bacillus species showed a zone of clearance of $30 \mathrm{~mm}(50 \mu \mathrm{L}), 28 \mathrm{~mm}(30 \mu \mathrm{L})$ and $29 \mathrm{~mm}(20 \mu \mathrm{L})$ on 24 hrs. of incubation.

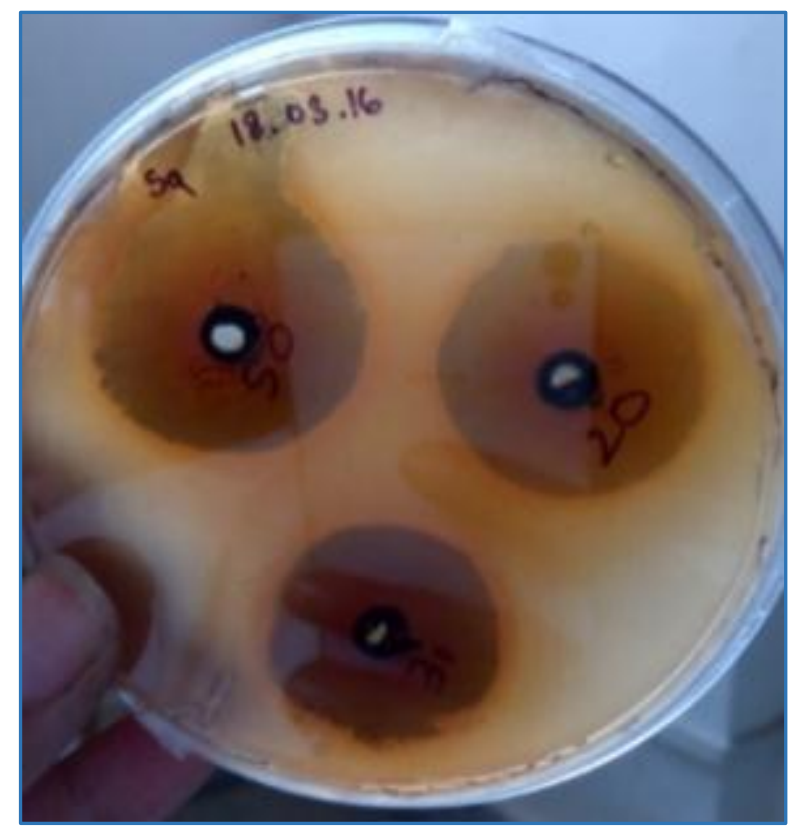

Figure 1(a). Staphylococcus xylosus

Figure 1. (a, b, c) Activity of Ethanol Extract of Piper Betel Leaf against Isolated Bacteria Zone of inhibition ( $\mathrm{mm}$ ) of P. betel leaf (Ethanol extract)

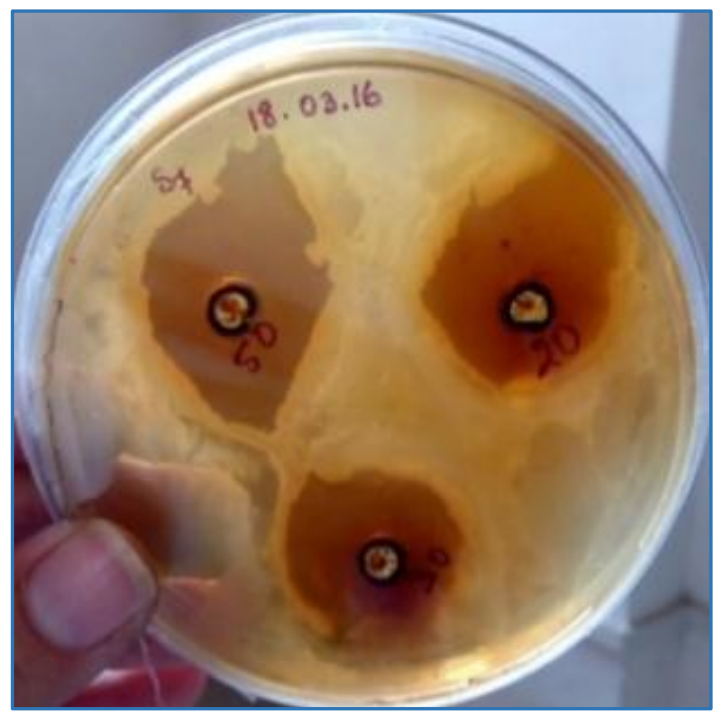

Figure 1(b). Klebsiella pneumoniae

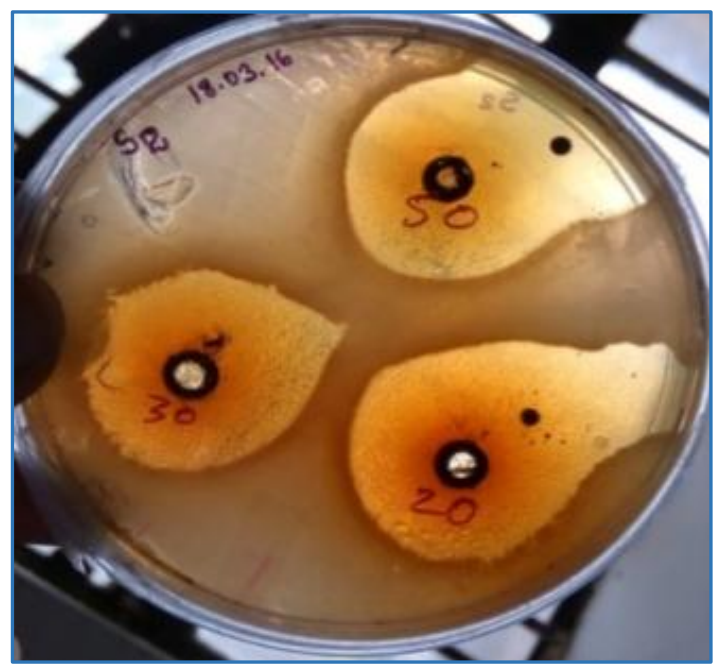

Figure 1(c). Bacillus sp. 


\begin{tabular}{|c|c|c|c|c|}
\hline \multirow{3}{*}{ Test Organisms } & \multirow{6}{*}{$24 \mathrm{hrs}$. } & \multicolumn{3}{|c|}{ Concentration $(\mu \mathrm{L})$} \\
\hline & & 50 & 30 & 20 \\
\hline & & & & \\
\hline Staphylococcus xylosus & & 40 & 29 & 27 \\
\hline Klebsiella pneumoniae & & 30 & 25 & 23 \\
\hline Bacillus species & & 30 & 28 & 29 \\
\hline $\begin{array}{l}\text { Table 3. Zon } \\
\text { of P. Betel L }\end{array}$ & $\begin{array}{l}\text { of Inhi } \\
\text { f(Etho }\end{array}$ & ion ( & & \\
\hline
\end{tabular}

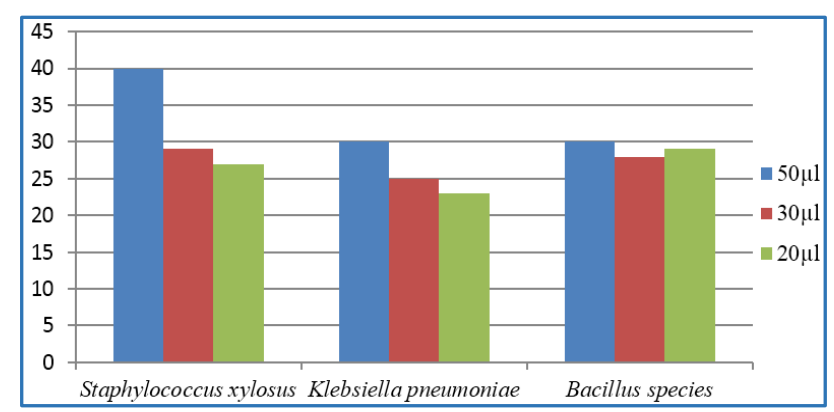

Figure 2. Antibacterial Activity of Ethanol Extract

\section{Antibacterial Activity of Methanol Extract of Piper Betel} Leaf

The methanol extract of Piper betel leaf was effective against Staphylococcus xylosus and showed a zone of clearance of 27 $\mathrm{mm}(50 \mu \mathrm{L}), 20 \mathrm{~mm}(30 \mu \mathrm{L})$ and $20(20 \mu \mathrm{L})$ on $24 \mathrm{hrs}$. incubation. The methanol extract was effective against Klebsiella pneumoniae and showed a zone of clearance of 16 $\mathrm{mm}(50 \mu \mathrm{L}), 16 \mathrm{~mm}$ (in $30 \mu \mathrm{L})$ and $15 \mathrm{~mm}(20 \mu \mathrm{L})$ on $24 \mathrm{hrs}$. incubation. The methanol extract was effective against Bacillus species and showed a zone of clearance of $38 \mathrm{~mm}(50 \mu \mathrm{L}), 20$ $\mathrm{mm}(30 \mu \mathrm{L})$ and $24 \mathrm{~mm}(20 \mu \mathrm{L})$ on $24 \mathrm{hrs}$. of incubation.

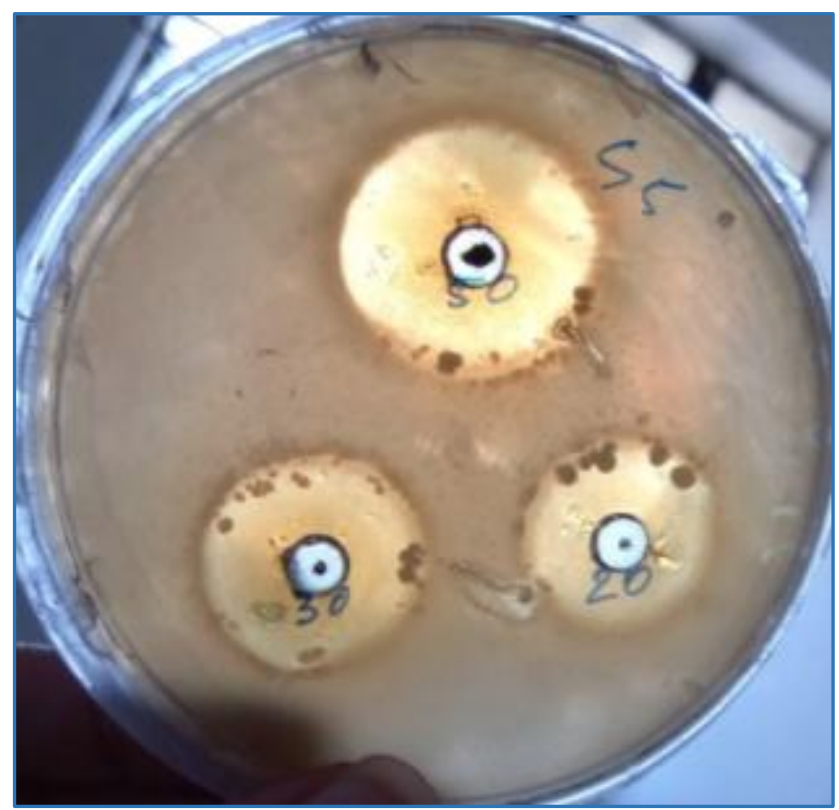

Figure 3(a). Staphylococcus xylosus

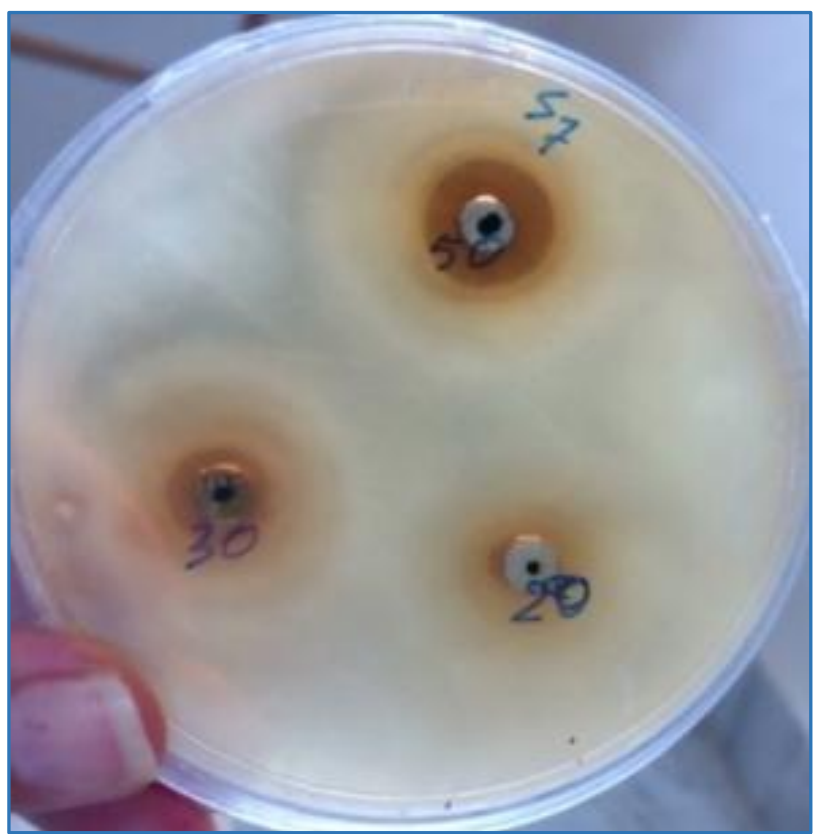

Figure 3(b). Klebsiella pneumoniae

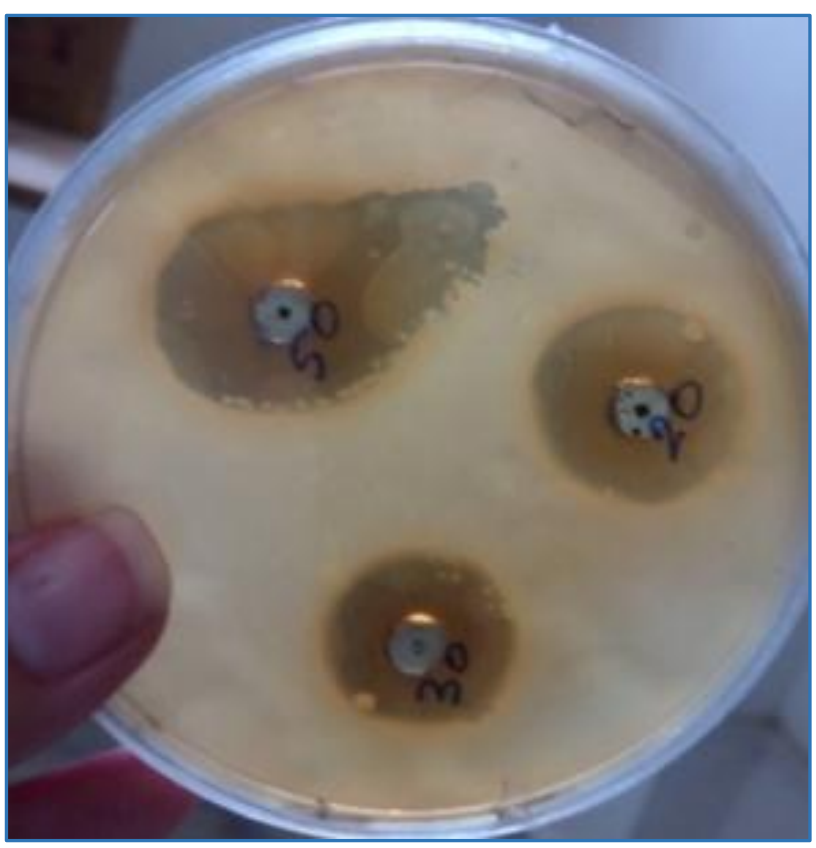

Figure 3(c). Bacillus sp.

Figure 3. (a, b, c) Activity of Methanol Extract of Piper Betel Leaf against Isolated Bacteria

Zone of Inhibition (mm) of P. betel leaf (methanol extract)

\begin{tabular}{|c|c|c|c|c|}
\hline \multirow{3}{*}{ Test Organisms } & \multirow{6}{*}{$24 \mathrm{hrs}$. } & \multicolumn{3}{|c|}{ Concentration $(\mu \mathrm{L})$} \\
\hline & & 50 & 30 & 20 \\
\hline & & & & \\
\hline Staphylococcus xylosus & & 27 & 20 & 20 \\
\hline Klebsiella pneumoniae & & 16 & 16 & 15 \\
\hline Bacillus species & & 38 & 20 & 24 \\
\hline \multicolumn{5}{|c|}{ Table 4. Zone of Inhibition ( $\mathrm{mm})$} \\
\hline
\end{tabular}




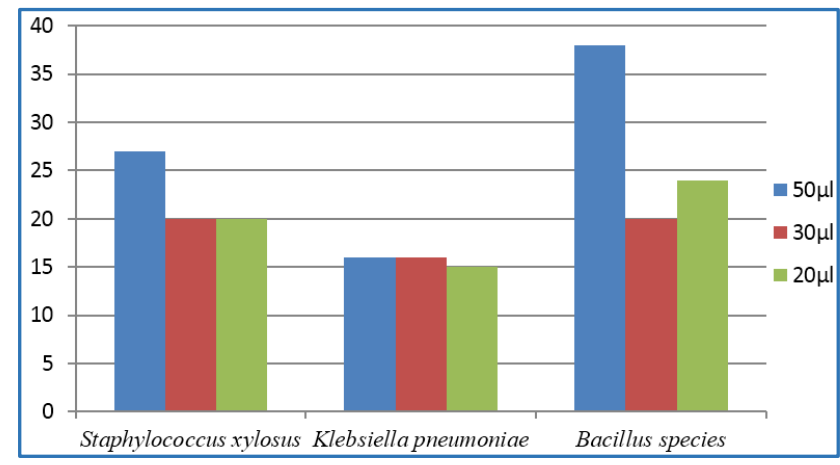

Figure 4. Antibacterial Activity of Methanol Extract

\section{Antibacterial activity of Aqueous extract of Piper Betel} Leaf

The aqueous extract of Piper betel leaf was effective against Staphylococcus xylosus and showed a zone of clearance of 24 $\mathrm{mm}(50 \mu \mathrm{L}), 17 \mathrm{~mm}(30 \mu \mathrm{L})$ and $17 \mathrm{~mm}(20 \mu \mathrm{L})$ on $24 \mathrm{hrs}$. incubation at $37^{\circ} \mathrm{C}$. The aqueous extract was effective against Klebsiella pneumoniae and showed a zone of clearance of 20 $(50 \mu \mathrm{L}), 18 \mathrm{~mm}(30 \mu \mathrm{L})$ and $14 \mathrm{~mm}(20 \mu \mathrm{L})$ on $24 \mathrm{hrs}$. incubation at $37^{\circ} \mathrm{C}$. The aqueous extract was effective against Bacillus species and showed a zone of clearance of $37 \mathrm{~mm}$ $(50 \mu \mathrm{L}), 22 \mathrm{~mm}(30 \mu \mathrm{L})$ and $18 \mathrm{~mm}(20 \mu \mathrm{L})$ on $24 \mathrm{hrs}$. of incubation at $37^{\circ} \mathrm{C}$.

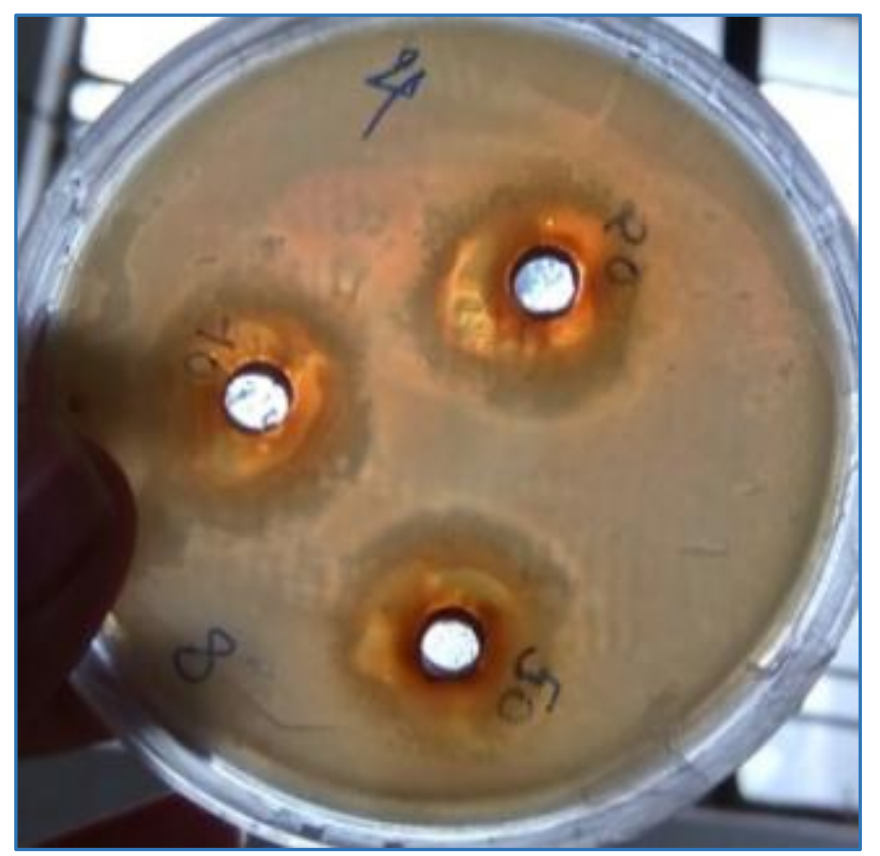

Figure 5(a). Staphylococcus xylosus

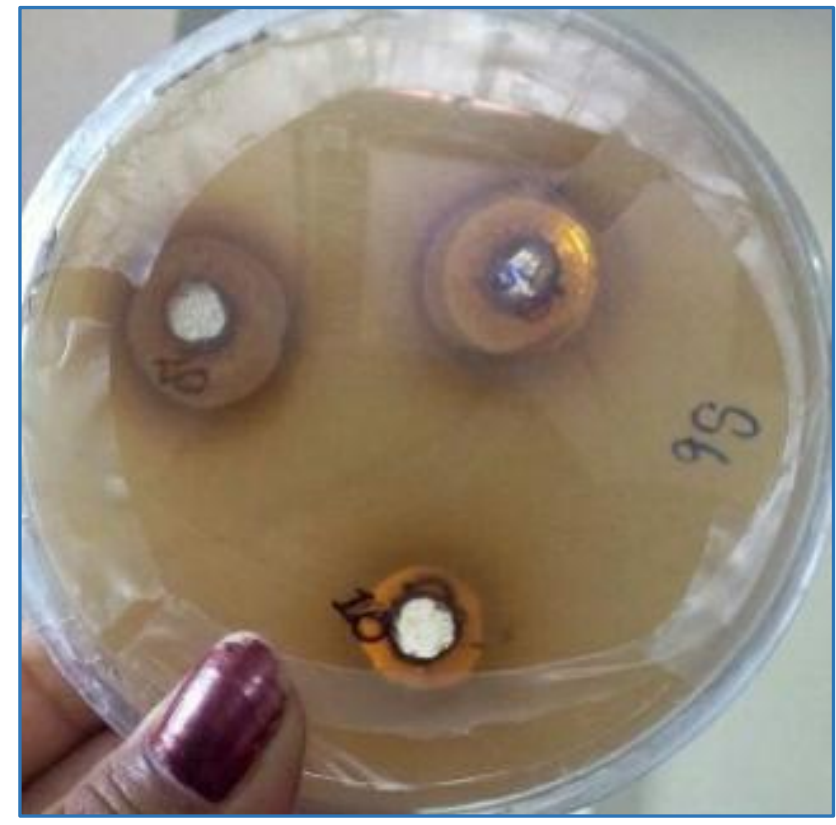

Figure 5(b). Klebsiella pneumoniae

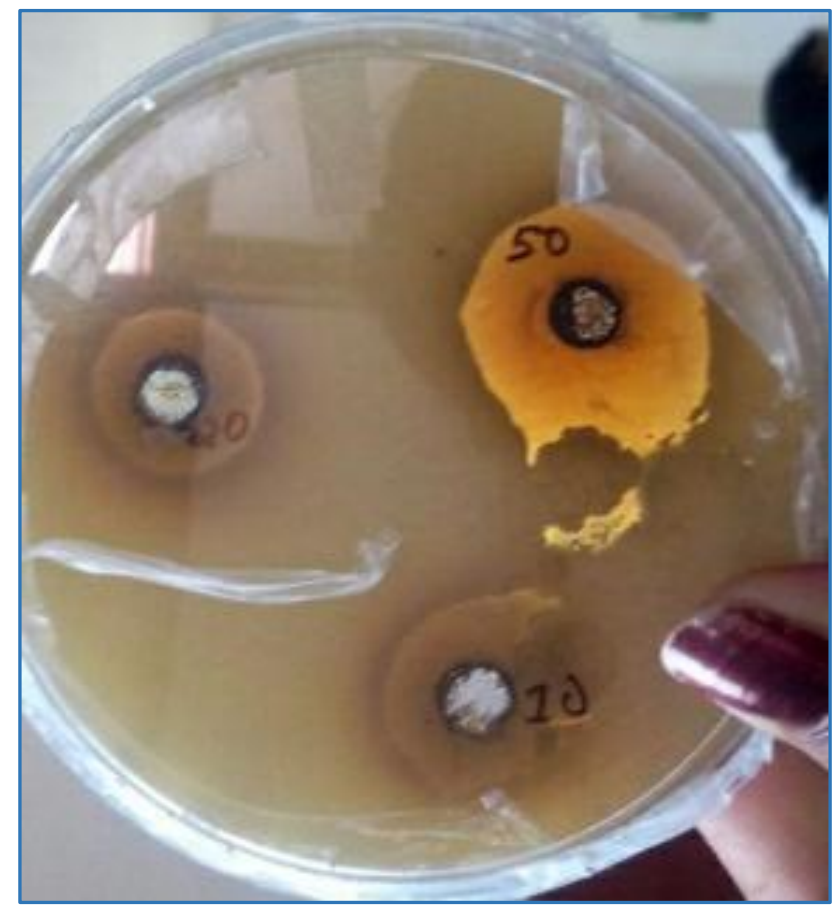

Figure 5(c). Bacillus sp.

Figure $5(a, b, c)$. Activity of Aqueous Extract of Piper Betel Leaf against Isolated Bacteria

Zone of inhibition (mm) of P. betel leaf (Water extract)

\begin{tabular}{|c|c|c|c|c|}
\hline \multirow{3}{*}{ Test Organisms } & \multirow{6}{*}{$\begin{array}{c}24 \mathrm{hrs} \text {. Incubation } \\
\text { at } 37^{\circ} \mathrm{C}\end{array}$} & \multicolumn{3}{|c|}{ Concentration $(\mu \mathrm{L})$} \\
\hline & & 50 & 30 & 20 \\
\hline & & & & \\
\hline at $37^{\circ} \mathrm{C}$ & & 24 & 17 & 17 \\
\hline \multicolumn{4}{|l|}{ Klebsiella pneumoniae } & \\
\hline Bacillus species & & 37 & 22 & 18 \\
\hline
\end{tabular}




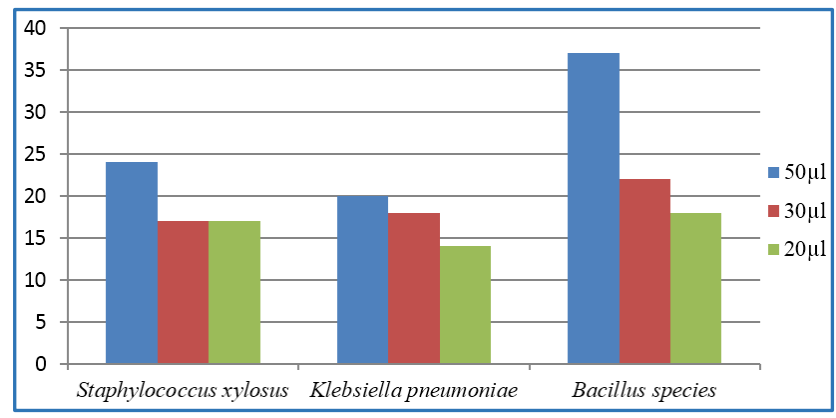

Figure 6. Activity of Aqueous Extract of Piper Betel Leaf against Isolated Bacteria

\section{Graphical Representation}

Comparative studies on the activity of the extracts of the Piper betel leaf showed that ethanol extract showed the maximum zone of inhibition followed by methanol extract and aqueous against the isolated bacteria.

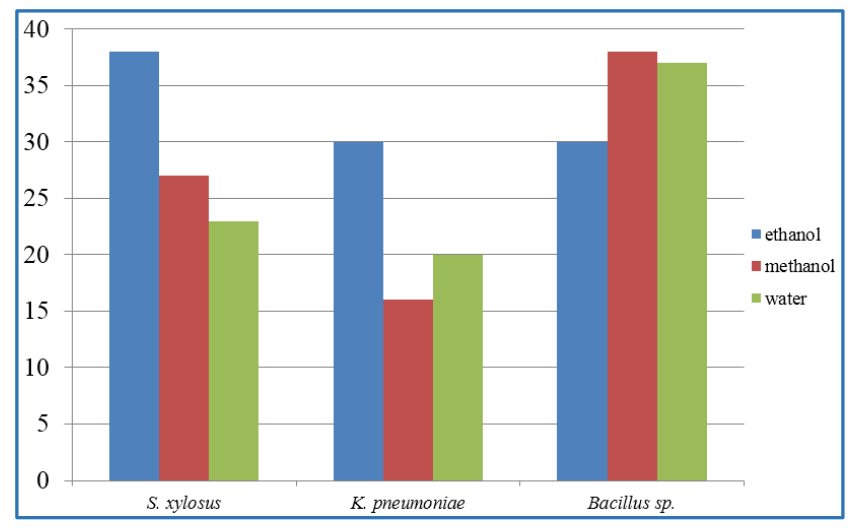

Figure 7. Comparative Activities of Piper Betel Leaf Extracted with Ethanol (Blue), Methanol (Pink) and Water (Green) against the Isolated Bacteria

\section{DISCUSSION}

Medicinal plants have been used to treat a variety of disorders including inflammatory conditions, infections with microorganisms, cancer, allergy and other disorders. Herbal medicines are a valuable and readily available resource for primary health care and complementary health system. They can be the best alternative for the available antibiotics against which the pathogens are adapting resistance. Phytochemicals are the bioactive component present in most of the plants. Plants show antibacterial activity because of the presence of different phytochemical compounds.

The present study is aimed at the evaluation of the antibacterial activity of Piper betel leaf extracts against the bacteria isolated from the oral region (Teeth); 30 samples of teeth swabs were collected by direct swabbing of the teeth of the patient suffering from dental caries. Isolation was done by swabbing the teeth swab on the nutrient agar plate and colonies were obtained. The bacteria present in the samples were identified by morphological and different biochemical tests.

In this present study, various phytochemical tests were performed for the Piper betel leaf extracts. Phytochemical analysis of P. betel leaf showed the presence of alkaloids, flavonoids, tannins, saponins, glycosides, protein and carbohydrates. Extracts were prepared from dried leaves of Piper betel plant using Ethanol, methanol and water. The antimicrobial activity of the extracts was determined by agarwell diffusion method. Ethanol, methanol and aqueous extracts of P. betel leaf were taken for the antibacterial studies against the bacterial isolated from the oral region (teeth). The test organisms were identified by VITEK instrument at Microbiology Laboratory, Down Town Hospital. The organisms were identified to be Staphylococcus xylosus, Klebsiella pneumoniae and Bacillus sp.

In the present study, the P. betel leaf extracts (Ethanol, methanol and aqueous) showed activity against the isolated bacteria.

In the present study, the ethanol extract was found to be most effective for its antibacterial activity against the bacterial strains. Widest zone of inhibition with a diameter of $40 \mathrm{~mm}$ was observed in case of Staphylococcus xylosus followed by Klebsiella pneumoniae with zone of inhibition extending up to $30 \mathrm{~mm}$ and Bacillus sp. with a zone of inhibition extending up to $30 \mathrm{~mm}$ (Shown in Table 7). The methanol extract was less effective for antibacterial activity as compared to Ethanol extract. Similarly, widest zone of inhibition with a diameter of $38 \mathrm{~mm}$ was observed in case of Bacillus sp. followed by Staphylococcus xylosus with zone of inhibition extending up to $27 \mathrm{~mm}$ and Klebsiella pneumoniae with a zone of $16 \mathrm{~mm}$ (Shown in Table 8). The water extract was least effective among all three extracts for its antibacterial activity. Like other two extracts, water extract came up with widest zone of inhibition with a diameter of $38 \mathrm{~mm}$ was observed in case of Bacillus sp. followed by Staphylococcus xylosus with a zone of $24 \mathrm{~mm}$ and Klebsiella pneumoniae with zone of inhibition extending up to $20 \mathrm{~mm}$ (Shown in Table 9).

In this study, it shows that the Piper betel leaf extracts successfully inhibited the growth of bacteria isolated from oral region (Teeth). Maximum activity was observed for ethanol extract followed by methanol extract and aqueous extract.

\section{CONCLUSION}

The plant sample was collected from the local market of Guwahati. The plant extracts were assayed for phytochemical compounds and antibacterial activity. Antibacterial activity was screened against the bacteria isolated from oral region (Teeth). Plant leaves were used for extraction of antibacterial metabolites using ethanol, methanol and water. All the extracts showed effect against the isolated bacteria. Of all the extracts, ethanol extract was most effective for its antibacterial activity against the isolated bacteria from oral region (Teeth) followed by methanol extract and aqueous extract. So from the present study, it can be concluded that Piper betel leaf can be a tool for fighting against the oral pathogenic bacteria which are gaining resistance to the drugs available in the market.

\section{REFERENCES}

1. Ekpendu TO, Akshomeju AA, Ologun JI. Antiinflammatory antimicrobial activity. Letters in applied microbiology 1994;30:379-84.

2. Iwu MW, Duncan AR, Okunji CO. New antimicrobials of plant origin. In: Janick J. edr. Perspectives on New crops and new uses. Alexandria, VA: ASHS Press 1999:457-62.

3. Bangash FA, Hashmi AN, Mahboob A, et al. In-vitro antibacterial activity of piper betel leaf extracts. Journal of Applied Pharmacy 2012;03(04):639-46.

4. Wealth Asia. Asian Health Environmental and Allied Database. Piper betel Linn. (Piperaceae). Traditional Asian Medicines and Natural Products. Monograph. 1997. 
5. Parmar VS, Jain SC, Bisht KS. Phytochemistry of genus Piper. Phytochemistry 1997;46(4):597-673.

6. Guha P. Betel leaf: the neglected green gold of India. Agricultural and food department, indian institute of technology, Kharagpur, West Bengal, India. J Hum Ecol 2006;19(2):87-93.

7. Piperbetel.http://www.homeremediesguide.com/herbs/ betel-leaves.html.

8. Betel. http://en.wikipedia.org/wiki/Betel. 4 August, 2014.
9. Chakraborty D, Shah B. Antimicrobial, anti-oxidative and anti-hemolytic activity of piper betel leaf. International Journal of Pharmacy and Pharmaceutical Sciences 2011;3(Suppl 3):192-9.

10. Kumari OS, Rao NB. Phyto chemical analysis of betel leaf extract. World Journal of Pharmacy and Pharmaceutical Sciences 2015;4(1):699-703. 